\title{
Detection of Cryptosporidium spp and other intestinal parasites in children with acute diarrhea and severe dehydration in Rio de Janeiro
}

\author{
Detecção de Cryptosporidium spp e outros parasitas intestinais em crianças \\ com diarréia aguda e desidratação grave no Rio de Janeiro
}

\author{
Filipe Anibal Carvalho-Costa ${ }^{1,2}$, Alessandra Queiroga Gonçalves ${ }^{1}$, Sandra Laranjeira Lassance ${ }^{1}$, \\ Carla Pontes de Albuquerque ${ }^{3}$, José Paulo Gagliardi Leite ${ }^{4}$ \\ and Márcio Neves Bóia ${ }^{1,5}$
}

\begin{abstract}
The objective of the present study was to estimate the frequency of infection by Cryptosporidium spp and other intestinal parasites in dehydrated children with gastroenteritis who were admitted to a pediatric hospital. Stool examinations from 218 children were performed. Cryptosporidium spp was identified in eighteen out of 193 stool samples (9.3\%) subjected to safranin-methylene blue staining. Giardia lamblia was detected in ten out of 213 (4.7\%) samples examined via the direct or Ritchie methods. Other parasites identified were Ascaris lumbricoides (4.2\%), Blastocystis hominis (1.4\%), Entamoeba coli (0.9\%), Entamoeba histolytica/Entamoeba dispar (0.5\%), Endolimax nana (0.5\%), Trichuris trichiura (0.5\%) and Enterobius vermicularis (0.5\%).
\end{abstract}

Key-words: Cryptosporidium spp. Acute diarrhea. Children. Stool examination.

\section{RESUMO}

O objetivo do presente estudo foi estimar a freqüência das infecções por Cryptosporidium spp e outros parasitas intestinais em crianças desidratadas com gastroenterite, internadas em um hospital pediátrico. Exames de fezes de 218 crianças foram realizados. Cryptosporidium spp foi detectado em 18 de 193 (9,3\%) amostras fecais submetidas à coloração pela safranina/azul-de-metileno. Giardia lamblia foi detectada em dez de 213 (4,7\%) amostras submetidas ao exame direto ou ao método de Ritchie. Também foram identificados Ascaris lumbricoides (4,2\%), Blastocystis hominis (1,4\%), Entamoeba coli (0,9\%), Entamoeba histolytica/Entamoeba dispar (0,5\%), Endolimax nana ( $0,5 \%)$, Trichuris trichiura (0,5\%) and Enterobius vermicularis $(0,5 \%)$.

Palavras-chaves: Cryptosporidium spp. Diarréia aguda. Crianças. Exame de fezes.

Acute diarrhea and dehydration are major causes of children mortality, causing about 3.3 million deaths yearly, on a global scale ${ }^{4}$. Cryptosporidium spp is a leading cause of diarrhea in children in developing countries ${ }^{5}$. Diarrhea caused by Cryptosporidium spp may be severe and chronic in immunocompromised individuals, such as patients with acquired immunodeficiency syndrome or in severely malnourished children ${ }^{13}$. Cryptosporidiosis may be transmitted by direct person-to-person contact, contact with infected animals or ingestion of contaminated water or food ${ }^{7}$.
In Brazil, up to $17 \%$ of cases of childhood gastroenteritis have been shown to be associated with cryptosporidiosis ${ }^{6}{ }^{10}$. Other intestinal parasites, such as Giardia lamblia, Entamoeba bistolytica and Blastocystis bominis are associated with gastroenteritis in children ${ }^{12}{ }^{17}$.

The purpose of this study was to estimate the frequency of infection due to Cryptosporidium spp and other intestinal parasites, among dehydrated children with acute diarrhea admitted for venous fluid therapy in a pediatric hospital in Rio de Janeiro, Brazil.

\footnotetext{
1. Laboratório de Doenças Parasitárias, Departamento de Medicina Tropical, Instituto Oswaldo Cruz, Fundação Oswaldo Cruz, Rio de Janeiro, RJ. 2. Hospital Municipal Souza Aguiar, Rio de Janeiro, RJ. 3. Hospital Municipal Salles Netto, Rio de Janeiro, RJ. 4. Laboratório de Virologia Comparada, Departamento de Virologia, Instituto Oswaldo Cruz, Fundação Oswaldo Cruz, Rio de Janeiro, RJ. 5. Disciplina de Doenças Infecciosas e Parasitárias, Faculdade de Ciências Médicas, Universidade do Estado do Rio de Janeiro, Rio de Janeiro, Brasil.

Address to: Dr. Filipe Anibal Carvalho-Costa. Laboratório de Doenças Parasitárias/Depto. de Medicina Tropical/IOC/FIOCRUZ. Av. Brasil, 4365, 21045-900 Rio de Janeiro, RJ. Telefax: $55212280-3740$

e-mail: guaratiba@ioc.fiocruz.br

Recebido para publicação em 18/8/2006

Aceito em 2/5/2007
} 
Table 1 - Frequency of detection of intestinal parasites by age groups in children with acute diarrhea in Rio de Janeiro.

\begin{tabular}{lcccccc}
\hline & \multicolumn{7}{c}{ Age groups (months) } \\
\cline { 2 - 7 } Parasites & $0-6$ & $7-12$ & $13-24$ & $25-60$ & Not & Total \\
& & & & & defined \\
\hline Cryptosporidium spp. & $2 / 33(6.1)$ & $6 / 55(10.9)$ & $659(10.2)$ & $3 / 30(10)$ & $1 / 16(6.3)$ & $18193(9.3)$ \\
Giardia lamblia & $1 / 39(2.6)$ & $4 / 61(6.6)$ & - & $4 / 33(12.1)$ & $1 / 19(5.3)$ & $10213(4.7)$ \\
Blastocystis hominis & - & - & - & $3 / 33(9)$ & - & $3 / 213(1.4)$ \\
Entamoeba coli & - & - & $1 / 61(1.6)$ & $1 / 33(3)$ & - & $2 / 213(0.9)$ \\
E. histolytica/E. dispar & - & - & - & $1 / 33(3)$ & - & $1 / 213(0.5)$ \\
Endolimax nana & - & - & - & $1 / 33(3)$ & - & $1 / 213(0.5)$ \\
Ascaris lumbricoides & - & $3661(4.9)$ & $5 / 61(8.2)$ & $1 / 33(3)$ & - & $9 / 213(4.2)$ \\
Trichuris trichiura & - & - & $1 / 61(1.6)$ & - & - & $1 / 213(0.5)$ \\
Enterobius vermicularis & - & - & - & - & $1 / 19(5.3)$ & $1 / 213(0.5)$ \\
\hline E: Entamoeba & & & & & &
\end{tabular}

The survey was carried out from February 2005 to February 2006 and involved 218 children aged six to 60 months (mean = $15.5 \pm 11.8$ months) in Salles Netto Municipal Hospital, a pediatric hospital situated downtown in Rio de Janeiro. The children in this study had low socioeconomic status and the majority lived in urban slums. All subjects presented acute diarrhea and were admitted for venous fluid therapy. Stool samples were collected in plastic fecal collectors without preservatives. After direct examination $(n=192)$, a preservative (SAF - sodium acetate, acetic acid and formalin) was added to the sample, in order to perform the Ritchie $^{14}(n=189)$ and safranin-methylene blue ${ }^{3}(n=193)$ staining methods. The data were processed in Epilnfo 2000 v.3.3.2 and presented as descriptive statistics. This study was approved by the Research Ethics Committee of the Evandro Chagas Research Institute, Oswaldo Cruz Foundation. The children were included after informed consent was given by their parents or the adult responsible for them.

Out of 218 samples, 40 (18.3\%) were positive for any parasite. Table 1 shows that Cryptosporidium spp were identified in eighteen out of 193 (9.3\%) stool samples subjected to the safranin-methylene blue method. Giardia lamblia was detected in ten out of 213 (4.7\%) samples examined through direct or Ritchie methods. Other parasites identified were Ascaris lumbricoides (4.2\%), Blastocystis hominis (1.4\%), Entamoeba coli (0.9\%), Entamoeba histolytica/Entamoeba dispar (0.5\%), Endolimax nana (0.5\%), Trichuris trichiura (0.5\%) and Enterobius vermicularis $(0.5 \%)$.

The present survey showed that Cryptosporidium spp was frequently detected in children admitted with acute diarrhea, among the study population.

Cryptosporidiosis has social and environmental determinants and is more prevalent in unsanitary conditions. Oocysts are hardy, chlorine-resistant and have tiny size. Also, their zoonotic potential contributes to the high transmissibility ${ }^{59}$. Cryptosporidium spp has an interaction with malnutrition and development of chronic diarrhea $^{7}$ and effective treatment is sometimes needed.

In Brazil, Gennari-Cardoso studied 94 children aged zero to twelve years in Uberlândia, State of Minas Gerais, Brazil, and detected Cryptosporidium spp in $4.3 \%$ of them using the safranin-methylene blue method ${ }^{6}$. Mangini et $a l^{10}$ detected Cryptosporidium spp parasitism in $17.4 \%$ of children aged 1 to 48 months with diarrhea in São Paulo over a three-year period.

Orlandi ${ }^{13}$ identified Giardia lamblia in 19 out of 130 cases of acute diarrhea in Rondônia and four out of 43 age-matched controls $(p=0.37)$. This pathogen was detected in four out of 94 children with acute diarrhea in Santa Catarina by Schnack ${ }^{15}$, in a study that surprisingly identified Cryptosporidium spp in 80 (85.1\%) out of 94 stool samples, using an ELISA coproantigen detection method.

Although Blastocystis hominis has been associated with gastroenteritis in children, and has been detected in children with acute diarrhea in Jordan ${ }^{12}$, its real significance as an etiological agent in diarrheal disease has been discussed ${ }^{1}$. Brazilian studies on blastocystosis in immunocompetent children have been focusing on parasitological prevalence surveys rather than on Blastocystis hominis detection in diarrheic feces ${ }^{211}$.

We argue that better comprehension of the etiological profile of acute diarrhea in this study population is needed, and suggest that a surveillance system should be implemented for enteropathogen detection, including viruses and bacteria, performed in selected pediatric hospitals.

\section{ACKNOWLEDGEMENTS}

We thank Dr. José Carlos dos S. Teixeira and all staff at Hospital Municipal Salles Netto and Enilza Marcela do Nascimento from Hospital Municipal Souza Aguiar, for essential support during sample collection. To Laudecir Couto dos Santos for technical support.

\section{REFERENCES}

1. Amato Neto V, Rodriguez Alarcon RS, Gakiya E, Bezerra RC, Ferreira CS, Braz LM. Blastocystosis: controversy and indefinedness. Revista da Sociedade Brasileira de Medicina Tropical 36:515-517, 2003.

2. Amato Neto V, Rodriguez Alarcon RS, Gakiya E, Ferreira CS, Bezerra RC, Santos AG. Blastocystosis: a high proportion of cases found in schoolchildren of Sao Paulo, State of Sao Paulo, Brazil. Revista da Sociedade Brasileira de Medicina Tropical 37:354-356, 2004. 
3. Baxby D, Blundell N, Hart CA. The development and performance of a simple sensitive method for the detection of Cryptosporidium oocysts in faeces. Journal of Hygiene-Cambridge 92:317-323, 1984.

4. Bern C, Martines J, Zoysa I, Glass RI. The magnitude of the global problem of diarrhoeal disease: a ten-year update. Bulletin of the World Health Organization 70:705-714, 1992.

5. Dillingham RA, Lima AA, Guerrant RL. Cryptosporidiosis: epidemiology and impact. Microbes and Infection 4:1059-1066, 2002.

6. Gennari-Cardoso ML, Costa-CruzJM, Castro E, Lima LM, Prudente DV. Cryptosporidium sp in children suffering from acute diarrhea at Uberlandia City, State of Minas Gerais, Brazil. Memórias do Instituto Oswaldo Cruz 91:551-554, 1996.

7. Griffiths JK. Human cryptosporidiosis: epidemiology, transmission, clinical disease, treatment, and diagnosis. Advances in Parasitology 40:37-85, 1998.

8. Khan WA, Rogers KA, Karim MM, Ahmed S, Hibberd PL, Calderwood SB, Ryan ET, Ward HD. Cryptosporidiosis among Bangladeshi children with diarrhea: a prospective, matched, case-control study of clinical features, epidemiology and systemic antibody responses. The American Journal of Tropical Medicine and Hygiene 71:412-419, 2004

9. Leav BA, Mackay M, Ward HD. Cryptosporidium species: new insights and old challenges. Clinical Infectious Diseases 36:903-908, 2003.

10. Mangini AC, Dias RM, Grisi SJ, Escobar AM, Torres DM, Zuba IP, Quadros CM, Chieffi PP. Cryptosporidium parasitism in children with acute diarrhea. Revista do Instituto de Medicina Tropical de São Paulo 34:341-345, 1992.
11. Nascimento SA, Moitinho ML. Blastocystis bominis and other intestinal parasites in a community of Pitanga City, Parana State, Brazil. Revista da Sociedade Brasileira de Medicina Tropical 47:213-217, 2005

12. Nimri LF, Meqdam M. Enteropathogens associated with cases of gastroenteritis in a rural population in Jordan. Clinical Microbiology and Infection 10:634-639, 2004

13. Orlandi PP, Silva T, Magalhaes GF, Alves F, Cunha RPA, Durlacher R, Silva LH Enteropathogens associated with diarrheal disease in infants of poor urban areas of Porto Velho, Rondonia: a preliminary study. Memórias do Instituto Oswaldo Cruz 96:621-625, 2001

14. Ritchie LS. An ether sedimentation technique for routine stool examinations. Bulletin US Army Medical Department 8:326, 1948.

15. Schnack FJ, Fontana L de M, Barbosa PR, Silva LS, Baillargeon CM, Barichello T, Povoa MM, Cavasini CE, Machado RL. Enteropathogens associated with diarrheal disease in infants ( $<5$ years old) in a population sample in Greater Metropolitan Criciuma, Santa Catarina State, Brazil. Cadernos de Saude Pública 19:1205-1208, 2003

16. Tzipori S, Ward H. Cryptosporidiosis: biology, pathogenesis and disease Microbes and Infection 4:1047-1058, 2002

17. Vargas M, Gascon J, Casals C, Schellenberg D, Urassa H, Kahigwa E, Ruiz J, Vila J. Etiology of diarrhea in children less than five years of age in Ifakara, Tanzania. The American Journal of Tropical Medicine and Hygiene 70:536-539, 2004 